\title{
The New Trade Bill: What's In It for R\&D
}

\section{Most accounts of what the 1,128-page document contains largely ignore a host of measures that could directly affect the R\&D community. The major ones-including several that directly target materials interests-are outlined here.}

For much of this year, the general news media regaled their audiences with controversies surrounding the trade bill, a mammoth piece of legislation, three years in the making. Initially, most accounts focused on its most contentious portionsmandatory worker-notification of pending plant closings and provisions calling for restrictions on the export of Alaskan-refined oil. The version that the President eventually signed into law on August 23 contained neither. But most accounts of what that 1,128-page document does contain largely ignore a host of measures that could directly affect the R\&D community. The major ones-including several that target materials interests specifically-are outlined here.

Most of the Omnibus Trade and Competitiveness Act of 1988 is directed at immediately improving shortcomings in U.S. trade policy, the growing U.S. budget deficit, and the U.S. balance of payments. Several smaller provisions address a longer term crisis: what Congress perceives as a decline in the vigor of the U.S. technological enterprise. The hodgepodge of initiatives adopted to address these problems span the gamut from expanded duties for the former National Bureau of Standards to new investments in science and engineering education. Widely regarded as the most important of these new measures are a pair of changes affecting the enforcement of U.S. patent, trademark and copyright laws.

\section{Intellectual Property Rights}

Until now, though importation of foreign products infringing on U.S. patents, trademarks and copyrights could be banneddoing so required first proving that the importing product would likely injure an efficiently operated U.S. industry. That was costly, time consuming-and many firms feared it might also require sharing closely guarded operational details or financial statements. No more. Under the new law, banning an infringing product's importation requires only showing that some U.S. industry-be it developing or established-exists that could be affected.

The second change would close an important loophole in process-patent law. Formerly, while importation of foreign products made by unlicensed users of a
U.S.-patented process could be banned, there was no way to collect financial damages for the patent's infringement. Under the new law, holders of U.S. process patents are for the first time allowed to sue for damages those firms that make or import products created with the infringing process.

\section{National Institute of Standards and Technology}

Among the more visible changes prompted by the new law is a renaming of the National Bureau of Standards (NBS) in Gaithersburg, Maryland. The new National Institute of Standards and Technology (NIST) will carry on NBS' former functions-largely the development of measurement standards and research in such areas as materials science, analytical chemistry, computer science, electronics and chemical physics-while assuming several advanced technology-outreach responsibilities.

Among NIST's new initiatives are the creation of:

- Regional centers for the transfer of technology. The first of these, previously authorized by Congress in anticipation of the bill's eventual passage, are three aimed at bringing new NBS-developed manufacturing-technology advances to small and medium-sized businesses. On July 18, NBS announced the availability of $\$ 5$ million in seed money to establish these regional nonprofit centers.

- A national technology-extension service. Unlike the Agriculture Department's extension service, this is not envisioned as a system to provide direct, government-run assistance to individuals or firms. Rather, it's expected to aid state and local technology-assistance programs by offering technical information, advice, and workshops or seminars for state officials on how to transfer technologies from the federal labs to local businesses. The new law also directs NIST to conduct and publish a survey of all state technology-transfer programs, including an evaluation of how well each currently uses the full range of available federal data and services, and whether it has been successful in improving the productivity and profitability of local businesses using these data and services.

- An information clearinghouse on state and local initiatives to promote technology innovation.

- A program to evaluate new inventions. NBS had for many years administered a similar program for energy-related inventions-estimating development costs, outlining schedules for developing inventions and identifying ways to finance those showing potential. The new program will expand this one to non-energyrelated technologies.

- An advanced technology research and development program to support industrial joint ventures. With the aim of helping U.S. businesses commercialize "significant new scientific discoveries and technologies rapidly," this program would help businesses, universities and independent research groups set up agreements for collaborative research. The goal is to create ventures that emulate-though likely on a more modest scale-the Sematech program (a research consortium involving the Defense Department and 14 U.S. chip manufacturers/users that is aimed at ensuring U.S. leadership in semiconductor manufacturing). Provided that emphasis is placed "on areas where [NIST] has scientific or technological expertise, on solving generic problems of specific industries, and on making those industries more competitive in world markets," this program is authorized to provide partial seed money for the collaborative ventures and to make available NIST equipment, facilities and personnel.

\section{Semiconductors and Superconductors}

Two new committees are being set up to advance strategic technologies. A 13member National Advisory Committee on Semiconductors is being charged with analyzing the needs and promise of this industry. Specifically, it's been assigned the role of "devising and promulgating a national semiconductor strategy, including research and development, the implementation of which will assure the continued leadership of the United States." This committee has been asked to identify areas where the U.S. industry is currently deficient, to identify emerging technologies that may impact national defense or competitiveness, and to develop R\&D strategies.

Members will include the Secretaries of Defense, Commerce and Energy, the director of the National Science Foundation, and the President's Science Adviser. The Science Adviser will select eight others from outside the government-half who are "eminent" in the semiconductor industry and half eminent in defense, technology or economic development. Their first 


\section{Semiconductors,} $\mathrm{Si}, \mathrm{GaAs}$, High $\mathrm{T}_{\mathrm{c}}$ Superconductors, Multi-layer Lattice
Structures

Process Products offers a series of rapid thermal modules that handle multiple processes and are available with many features. Our RTMs are capable of handling the industry's varied process requirements. For specific information on how our RTMs can be utilized for your processing needs, contact (508)689-3828 or FAX (508)686-5847.

\section{See us at The MRS Show}

Available features and capabilities include:

- Reduced Pressure (1 x 10-6 Torr)

- Mass Flow Gas Controllers

- Overpressure Activation

- I/R Temperature Sensing/Control

- Variable Ramps and Dwells

- Toxic Gas Handling

- $100 \% \mathrm{H}_{2}$ Almosphere

- Temperature Range $100-1200^{\circ} \mathrm{C}$

- Closed Loop Control

- Ramp Rate $0.1-300^{\circ} \mathrm{C} / \mathrm{sec}$

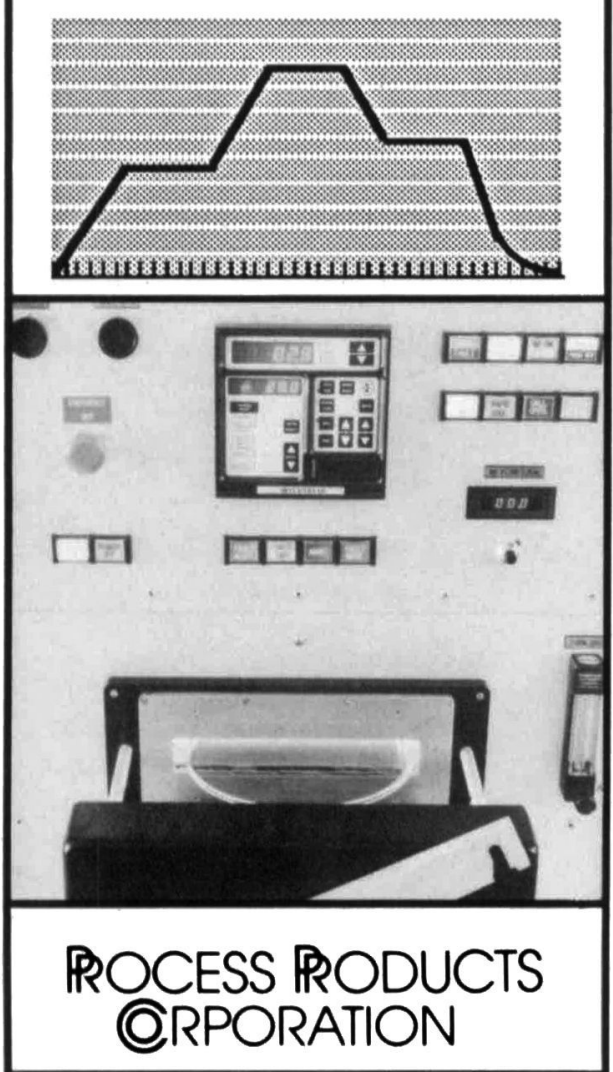

37 Flagship Drive N. Andover, MA 01845 meeting must be called within 90 days of the trade bill's passage into law.

A second, one-year National Commission on Superconductivity is being set up to "review all major policy issues regarding U.S. applications of recent research advances in superconductors." Its mission is the development of a national superconductivity strategy - to include the setting of $R \& D$ priorities. Chaired by a member of the private sector, this commission will include representatives of the National Academy of Sciences, the National Academy of Engineering, NASA, the Departments of Defense, Energy, Justice, Transportation, Treasury and Commerce (including NIST), and the National Critical Materials Council.

This commission has six months to submit a report to the President and Congress recommending ways to improve and coordinate not only the collection and dissemination of superconductivity research data, but also the funding of this research, and the development of its commercial and military applications. The report is also supposed to review foreign activities promoting superconductivity research and applications, and evaluate whether there is any need to increase U.S. funding of this research. Finally, the commission has been asked to assess the national-security impact of the United States' having to rely on foreign producers of superconductors.

The White House National Critical Materials Council (NCMC), which is coordinating this commission and providing its staff support, itself gained a lot from the new trade law. Within 30 days of the bill's enactment, NCMC-charged with developing a federal plan for advanced materials R\&Dwas to triple its technical staff (to six persons) and double its support staff (to two).

\section{Symmetrical Access to U.S. Research}

Over concern that foreign participants in U.S. science and technical exchanges are gaining far more from their involvement than their American colleagues can, the new law requires that future international exchanges be negotiated to ensure that access to research opportunities and facilities, and "the flow of scientific and technological information, are, to the maximum extent practicable, equitable and reciprocal." The Secretary of State has responsibility for implementing this policy. How the Secretary should do this is not spelled out beyond requiring that potential exchanges initially be reviewed by those federal agencies having the most expertise in the research area.

\section{Education}

One factor Congress identified as contributing to the erosion of U.S. competitiveness is the education of the American workforce. Today, Congress says, millions of workers are functionally or technologically illiterate, or lack the mathematics, science and other skills necessary to adapt to changes in the global economy. The new trade law includes several provisions aimed at attacking this problem.

Among those focusing on technical illiteracy are several "partnerships"-new programs to link schools, the business community, mathematics and science associations and other nonprofit organizations (including museums and libraries). One authorizes $\$ 20$ million in grants to improve the quality of instruction in elementary and secondary school science and math-particularly in economically depressed regions. The money can be used for anything from the purchase of better equipment to the development of "advanced placement" programs in science and math. A related $\$ 10$ million program aims to create similar partnerships to help educationally disadvantaged and gifted students-from grade schoolers through college undergraduates-receive special training in science, math and engineering.

A separate College and University Research Facilities and Instrumentation Modernization Program will earmark matching funds to upgrade aging equipment and facilities for studies in agriculture, strategic metals and minerals, energy, forestry and wood products, and ocean science. The National Science Foundation has been directed to establish a related Academic Research Facilities Modernization Program, funded at $\$ 85$ million in FY 1989. Another $\$ 7.5$ million a year for four years have been authorized to expand an existing Higher Education Act program to increase the participation of minority students in science and engineering research careers.

\section{Centimeters over Inches}

Finally, the new law declares it U.S. policy that the metric system is "the preferred system of weights and measures for U.S. trade and commerce," and requires each federal agency to use metric measurements in its procurements, grants and other business-related activities. To the extent possible, federal workers must go metric by 1992. Exceptions are allowed, however-such as when doing so would put U.S. researchers at a competitive disadvantage with foreign peers who are themselves developing a nonmetric product.

Please visit booth no. 917 at the MRS Show in Boston, November 29-December 1, 1988. 


\section{Holders and Conversions for TEMs}

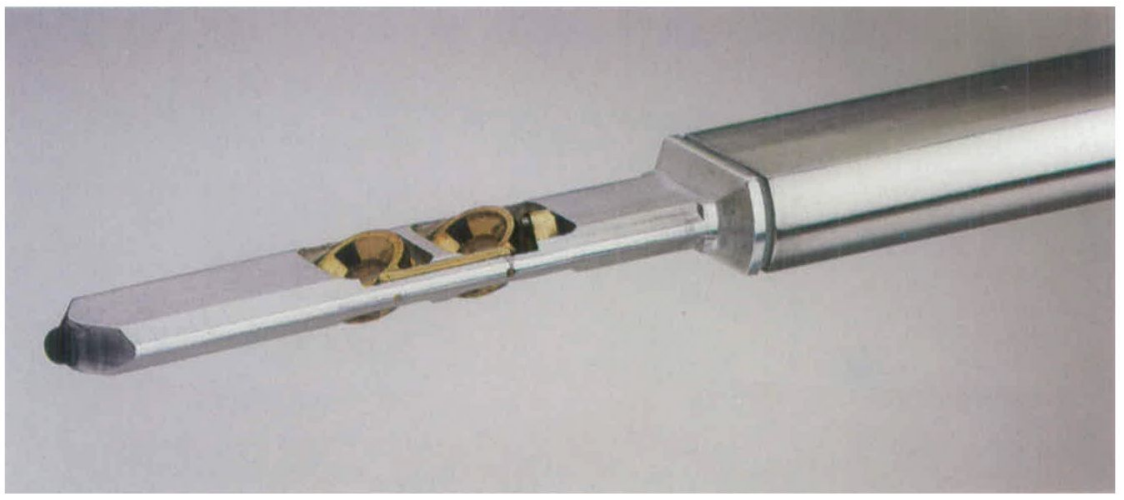

Twin specimen, double tilt holder

Gatan produced its first double tilt specimen holder in 1960 at a time when commercial TEMs offered only single tilt holders for stereo imaging. Since then we have made all types of specimen holder for almost every make and model of TEM.

Even today specialized specimen holders and stages remain a major part of our business and Gatan works closely with the leading TEM manufacturers to extend the versatility of electron microscopes through innovative holder design.

The sophistication of today's specimen holders inevitably makes them more delicate than simple single tilt types. For this reason, Gatan maintains excellent repair facillities capable of short turn around times so that should your Gatan holder be damaged, you will be without it for as short a time as is possible.

Gatan's designers are all experienced microscopists and understand the problems of specimen loading and manipulation. Our innovations include the Hexring ${ }^{\mathrm{TM}}$ specimen clamping system, the
Single tilt, multiple specimen holder
Clipring ${ }^{\mathrm{TM}}$ cryotransfer clamping system, the robust, reliable toggle tilt mechanism, the bubble free liquid nitrogen dewar and the antidrift device (US Patent $4,703,181)$.

Two of our recent products are shown here but our complete line includes:

${ }^{*} X$-ray analytical $(\mathrm{Be})$

Bulk analytical

$360^{\circ}$ Continuous Rotation $(\mathrm{Be})$

Ultra high tilt analytical

Twin specimen double tilt $(\mathrm{Be})$

Multiple specimen single tilt $(\mathrm{Be})$

*Vacuum transfer $(\mathrm{Be})$

*Heating

${ }^{*}$ Cooling $\left(\mathrm{LN}_{2}\right.$ and $\left.\mathrm{LHe}\right)(\mathrm{Be})$

Cryotransfer system

Micropositioning anticontaminator UHV stages (Philips TEMs)

Controlled atmosphere cells

( ${ }^{\star}$ Double and single tilt available)

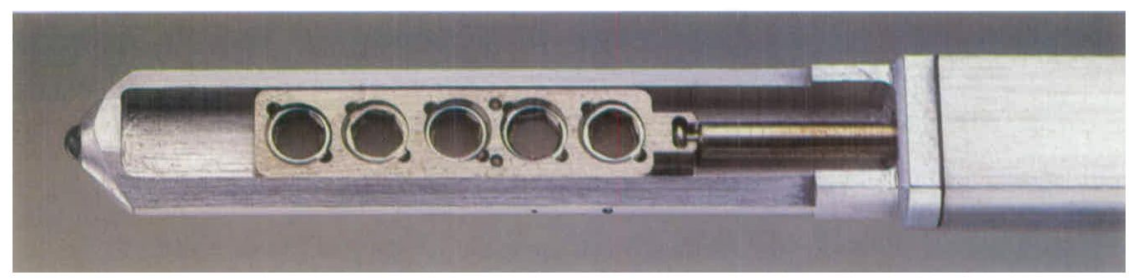

For further informationon specimen holders, TV systems, EELS, PEELSTM and TEM specimen preparation equipment, please call our main sales and service offices at:
Gatan Inc., Pleasanton, CA Tel. (415) 463-0200

Gatan Inc., Warrendale, PA Tel. (412) 776-5260
Gatan GmbH, München. FRG Tel. (089) 352374

Gatan Ltd.,High Wycombe, UK Tel. (0494) 26211

Please visit booth no. 309 at the MRS Show in Boston, 